\title{
ANALYSIS OF APPLICATION OF ANTIBACTERIAL AGENTS IN TEXTILES: SYSTEMATIC REVIEW
}

\author{
Marcelo Pinheiro Fontes ${ }^{a}$, Tatiana Barreto Rocha Neryra, Jeancarlo Pereira dos \\ Anjos $^{a}$
}

${ }^{a}$ Centro Universitário SENAI CIMATEC - Av. Orlando Gomes, 1845 - Piatã, 41650010, Salvador - BA.

\begin{abstract}
Currently, the search for the quality of life of human beings has increased. The development of textile materials that bring functionality, safety and protection has been growing. Textiles are known to facilitate the proliferation of microorganisms such as fungi and bacteria. Thus, the aim of this study was to carry out a systematic review on the main antibacterial agents used for applications in textile materials. The research allows the conclusion that silver-based compounds are the most prominent in the literature and that the search for new agents and applications enables new market niches for textile products.
\end{abstract}

Keywords: Textiles; Antibacterial; Bacteria.

\section{ANÁLISE DA APLICAÇÃO DE ANTIBACTERIANOS EM TÊXTEIS: REVISÃO SISTEMÁTICA}

Resumo Atualmente, a busca pela qualidade de vida dos seres humanos tem aumentado. O desenvolvimento de materiais têxteis que tragam funcionalidade, segurança e proteção tem sido crescente. Os têxteis são conhecidos como meio que facilitam a ploriferação de microorganismos com fungos e bactérias. Assim, 0 o objetivo deste estudo foi realizar uma revisão sistemática sobre os principais agentes antibacterianos utilizados para aplicações em materiais têxteis. A pesquisa permite a conclusão de que os compostos a base de prata são os mais destacados na literatura e que a busca de novos agentes e aplicações possibilita novos nichos de mercado para os produtos têxteis.

Palavras-chave: Têxteis; Antibacterianos; Bactérias. 


\section{INTRODUCTION}

The presence of the textile industry is indispensable in our daily lives seen in various applications such as clothing, home care, uniforms, and can be used in cars, buses, airplanes, life jackets and even in bulletproof vests [1].

Technical textiles are produced for a specific end use or application and can meet technical requirements with high performance in several segments, for example: safety issues (fireproof properties), civil construction (acoustic insulation) and the environment (filters and blankets for drainage), among others. Within the technical textiles, there is the group of antimicrobial textiles. Textiles incorporated with antimicrobial compounds have been present on the market for decades, being used in the most diverse applications, to prevent or inhibit the growth of microorganisms [2].

Textile products are seen as a good substrate for the growth of microorganisms, particularly fungi and bacteria. Textiles from natural raw materials such as cotton, linen and wool are more susceptible to invasion by microorganisms. On the contrary, synthetic fibers, being more hydrophobic, are considered more resistant to attack by microorganisms. However, the processes applied to these fibers can be responsible for decreasing their resistance [3]. The growth of microorganisms in textiles generates two different types of problems, depending on the type of fiber and environmental conditions. The first is related to deterioration in the form of reduced mechanical strength, discoloration, stains, etc. These problems usually occur in natural fiber fabrics. The second type is associated with health and hygiene, such as the generation of unpleasant odor, skin irritation, contamination by cross infections, etc. These types of problems are generated in fabrics of all types of fibers. For these reasons, it is necessary that the growth of microorganisms in the tissues be inhibited during their application and storage [4].

Microorganisms are small forms of life that generally cannot be seen by the human eye. These include a variety of microorganisms such as bacteria, fungi, algae and viruses. Pathogenic bacteria, or not, are single-celled organisms that reproduce in a hot, humid environment at a rate that doubles every 18 to 38 minutes. Essentially, three forms of bacteria are known, bacilli, coconut shapes and vibrion [5].

Antibacterial agents are the compound or substance that kills bacteria, prevents or inhibits their growth and reproduction and contributes to the claimed effects of the product in which it is included [4]. Triclosan antibacterial agents, silane compounds, ammonium quaternary, zinc pyrithione and silver-based compounds are the main antimicrobials used in textiles [6,7].

The choice of antibacterial agent to be applied to textiles must take into account some factors such as: (i) it must be effective against a wide spectrum of bacterial species, it must provide low toxicity to consumers, it must not harm other physical characteristics of the fabric, the finish must be compatible with chemical textile processes and must not produce toxic substances to the manufacturer, users and the environment [4].

The incorporation of antibacterial agents in textiles can happen in different ways, two examples of methods can be mentioned: one is the addition of nanoparticles during the extrusion of synthetic fibers, and the other is the incorporation during finishing processes using, for example, the sol-gel method. [1]. 
In this context, the objective of this study was to carry out a systematic review on the main antibacterial agents and the application in textiles.

\section{METHODOLOGY}

The methodology applied for the development of this article was a systematic review (Figure 1). To carry out this research, the method developed followed the following steps: i) search using the keywords: "textile", "antibacterial", and "bacteria"; ii) access to databases: ScienceDirect, Scopus and Capes (Brazilian Portal); iii) the inclusion criteria defined for conducting the search for publications were: the relevance of the contents in relation to the topic addressed in this work, works published in the last 15 years (period 2005 to 2020) in Portuguese and English, and works available in their entirety .; iv) the selection of publications was carried out by reading the abstracts, according to the established filter (Figure 1).

The search in the selected databases took place through online access, between the months of April to July 2020. All works published outside the period mentioned in the methodology, in the defined languages and articles with availability for a fee were excluded. The Google Scholar database was used in order to add to the content of the article.

Figure 1. Flowchart of the systematic review methodology

\section{SYSTEMATIC REVIEW}

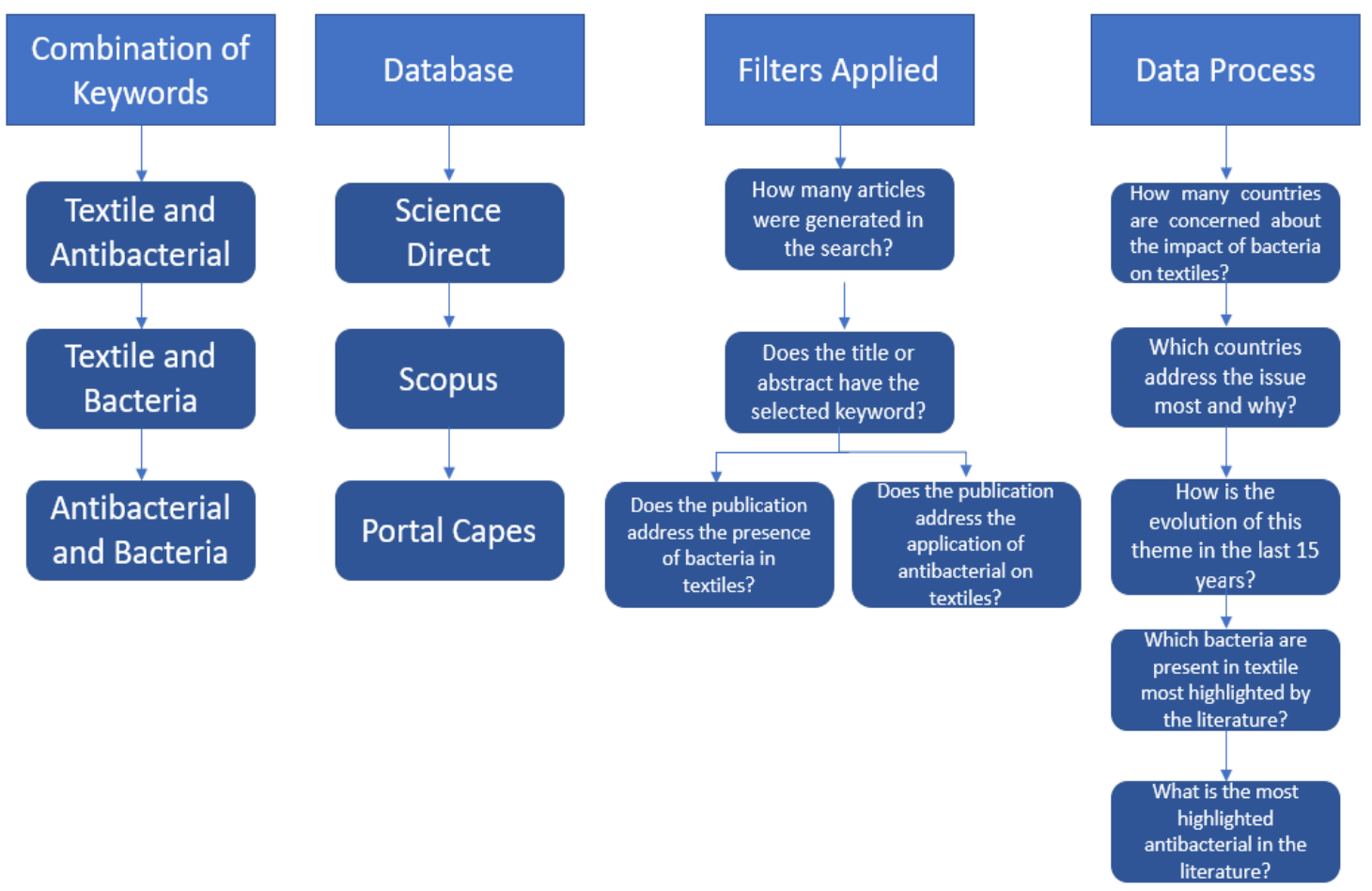

Elaborated by the authors 


\section{RESULTS AND DISCUSSION}

The results of a systematic review from the applied methodology can be divided into three topics based on the treatment of the data performed.

\section{1 - Relevance of the topic related to research in the period from 2005 to 2020}

The revelation of the theme regarding research on antibacterial agents in textiles can be demonstrated in the results obtained through the application of the filters established in the systematic review methodology (Figure 01). Table 01 shows the result of the number of articles obtained and the number of articles selected to compose this article.

When analyzing the three combinations, we found that using the keyword "textile" with one of the other two keywords, "antibacterial" or "bacterial" results in confirmation of the concern for the presence of bacteria in textiles and in the search for applications that eliminate or inhibit the proliferation of bacteria by the increasing the number of papers related to the topic.

The result of combining only the keywords "antibacterial" and "bacteria" shows a higher number of researches, which show that the concern with the presence of bacteria is not only in textiles.

Table 01 - Number of papers obtained and the number of papers selected according to the applied methodology

\begin{tabular}{|c|c|c|c|}
\hline $\begin{array}{c}\text { Combination of } \\
\text { Keywords }\end{array}$ & $\begin{array}{c}\text { Science Direct } \\
\text { Papers found / Papers used }\end{array}$ & Papers found / Papers used & Papers found / Papers used \\
\hline Textile and Antibacterial & $65 / 2$ & $39 / 3$ & $29 / 2$ \\
\hline Textile and Bacteria & $46 / 1$ & $83 / 2$ & $52 / 1$ \\
\hline Antibacterial and Bacteria & $151 / 0$ & $84 / 0$ & $72 / 0$ \\
\hline
\end{tabular}

Elaborated by the authors

From the systematic review carried out, it was possible to quantify the countries that publish the most on this topic (Figure 2) and also show the evolution over the $15 y e a r$ period (Figure 3). The countries that most publish on the subject are India, China and Iran, which are also considered global textile hubs and exporters to most countries in the world.

With regard to research on the topic, we can conclude that it has been a topic of interest since the beginning of the researched period and also that the number of searches has increased in the last 5 years, closely related to the increased demand for antibacterial solutions in tissues. 
Figure 02: Countries that publish the most on the research topic

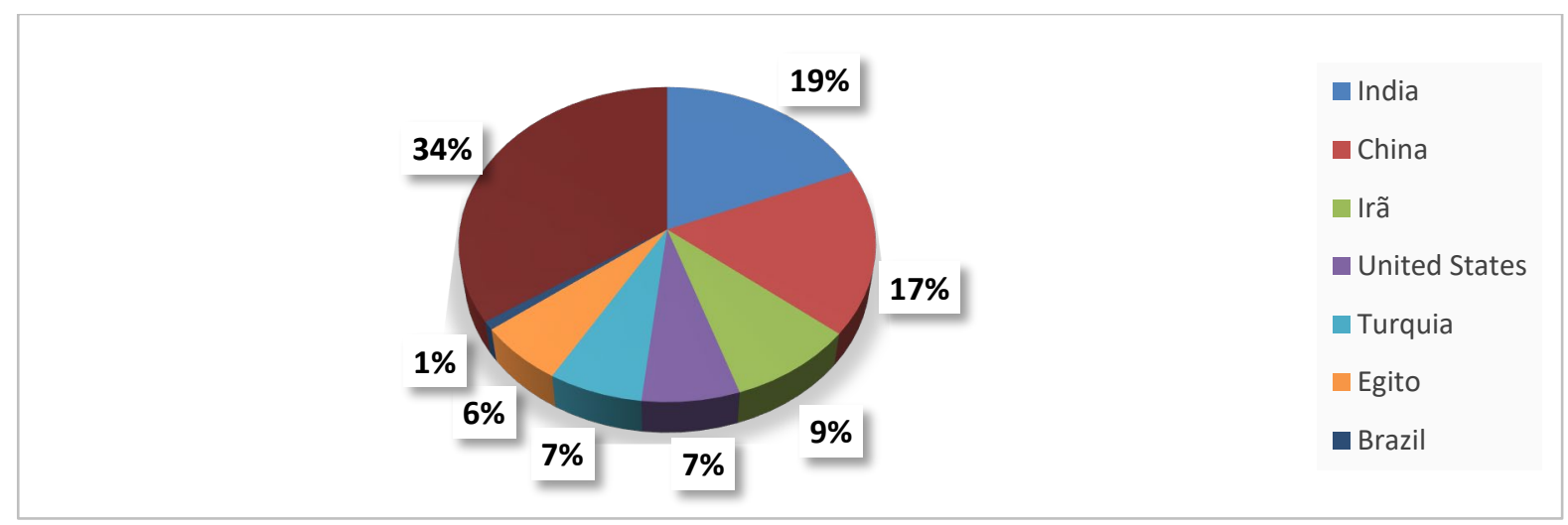

Elaborated by the authors

Figure 3: Percentage ratio (considering $n=809$ ) of papers published about the use of the antibacterial agents in textiles over the past 15 years.

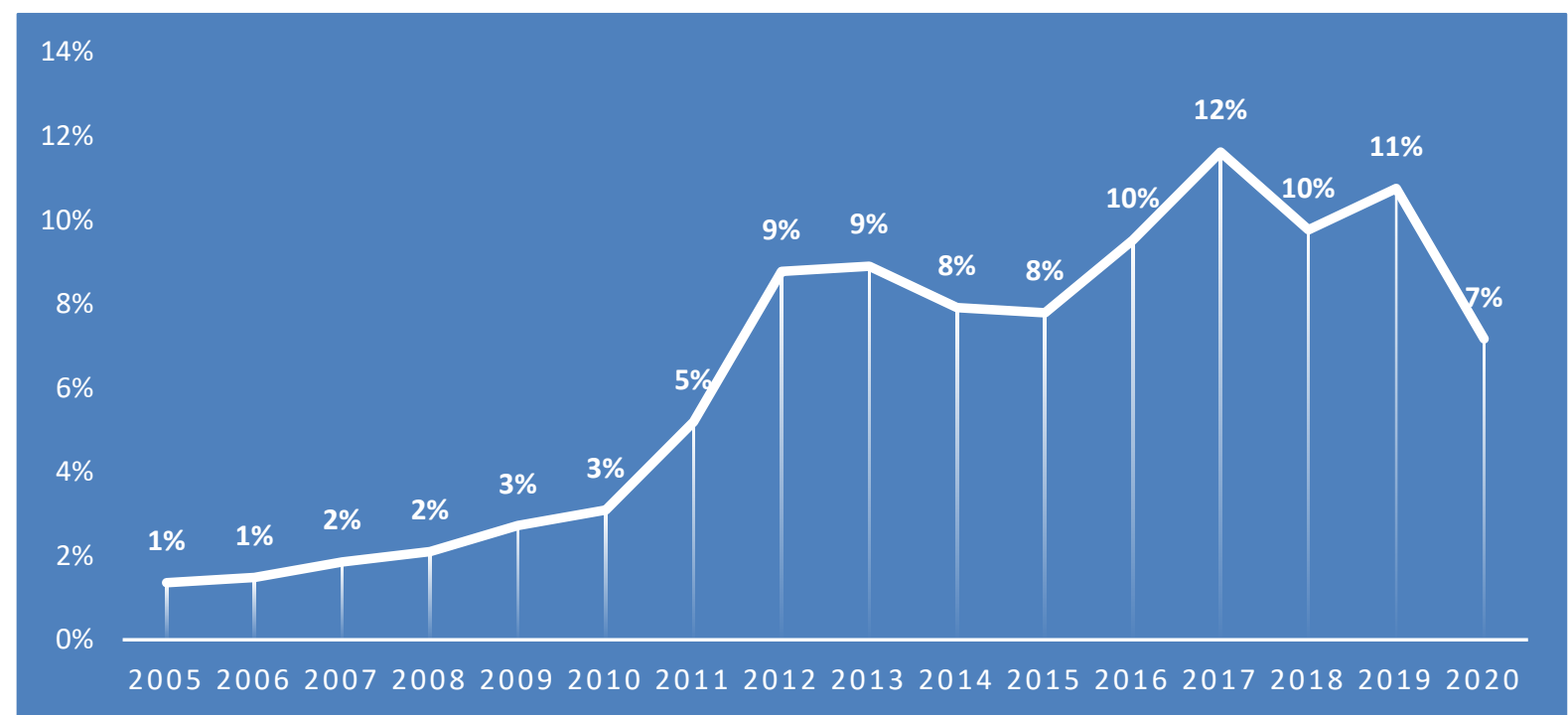

Elaborated by the authors

\section{2 - Main bacteria found in textiles}

Bacteria are single-celled organisms that grow very quickly under heat and humidity. In addition, the family of bacteria can be classified into two categories: grampositive (Staphylococcus aureus) and gram-negative (Escherichia coli). Some specific types of bacteria are pathogenic and cause cross infections. Fungi, molds or mildew are complex organisms with a slow growth rate. They stain the fabric and decrease the performance properties of the fabrics [8].

Gram-positive bacteria are colored purple, while Gram-negative bacteria are colored pink or red by the Gram staining technique. The Gram-positive cell wall consists of a single homogeneous $20-80 \mathrm{~nm}$ thickness peptidoglycan or murein layer located outside the plasma membrane, as shown in Figure 04 (B). The gram-negative wall is quite complex. It has a 1-3 nm layer of peptidoglycan surrounded by an outer 
membrane 7-8 $\mathrm{nm}$ thickness [4]. Figure 04 shows an example of a bacteria (A) and the difference in the cell wall of Gram-positive and Gram-negative bacteria.

Figure 04 - Schematic structure of a bacterium (A) different from the cell wall of Gram-positive and Gram-negative bacteria (B).

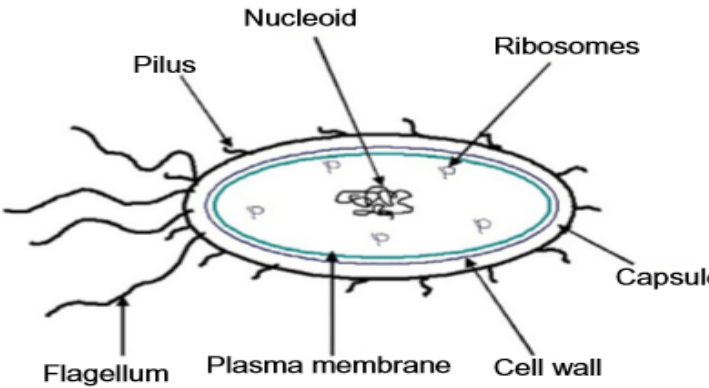

(A)

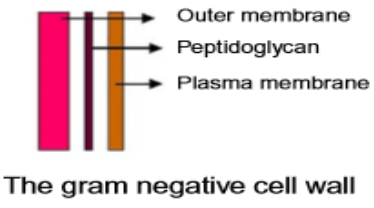

(B)

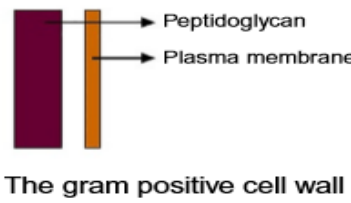

The gram positive cell wall

Source: Puwar, 2019.

Examples of bacteria and fungi found on the surface of tissues and their possible causes to humans and their practical applications are presented in Table 02.

Table 02: Representative classes of microorganisms found in textiles.

\begin{tabular}{|l|l|l|l|}
\hline S. no. & Species & Resulting disease or condition & End uses \\
\hline Gram-positive bacteria & Staphylococcus aureus & Pyogneic infections & Hygienic, medial \\
\hline 1 & Staphylococcus epidermidis & Body odor & Aesthetic \\
\hline $\mathbf{2}$ & Corynebacterium diphtheroides & Body odor & Aesthetic \\
\hline 4 & Bacillus subtilis & & Hygiene \\
\hline 5 & Brevibacterium ammoniagenes & Diaper rash & \\
\hline 6 Gam- negative bacteria & Escherichia coli & Infections of urogenital tract & Medical, aesthetic \\
\hline 6 & Klebsiella pneumoniae & Pneumonia & Medical \\
\hline 7 & Proteus mirabilis & Urinary infection & Medical \\
\hline 9 & Pseudomonas aeruginosa & Infection of wounds & Hygiene \\
\hline 10 & Epidermophyton floccosum & Infection of skin & \\
\hline
\end{tabular}

Source: Puwar, 2019 (adapted).

\section{3 - Antibacterial agents most commonly used in textiles}

The result of the research showed that the majority of publications indicate the following antibacterial agents as most used in textile applications today, namely: triclosan, silane compounds, ammonium quaternary, zinc pyrithione and silver-based compounds $[6,7]$. 
Silver compounds is by far the most widely used in textiles in general. For synthetic fibers, silver particles can be incorporated into the polymer before extrusion or before the formation of nanofibers using electrospinning. During use, silver diffuses on the fiber surface and forms silver ions in the presence of moisture. The rate of silver release can be influenced by the chemical and physical characteristics of the fiber and the amount of silver in the fiber $[9,10,11]$.

There are two mechanisms that justify the bactericidal activity of silver. In the first, they act in a way to damage one or more essential organelles present in these organisms. According to the other mechanism, they damage the cell wall [1] as shown in Figure 5.

Figure 05 - Fabric with silver particles and bactericidal action.

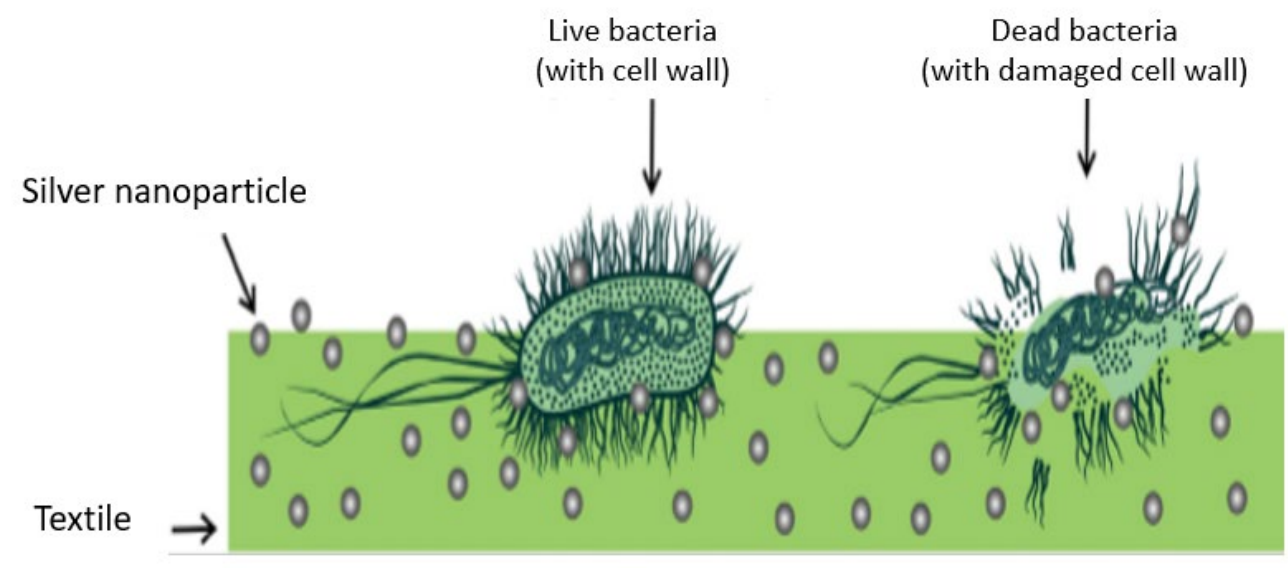

Source: Gomes, 2016(adapted)

\section{CONCLUSION}

This article aimed to provide an overview of the application of antibacterial agents in textiles. Through a systematic review as a resource to obtain information in the literature that proves the importance of the topic and also as a source of information on the main bacteria found in textiles and their side effects for the population that consumes textile articles in general. As well as solutions to these problems through the application of antibacterial agents, such as silver compounds. Future research seeks the insertion of new agents and new applications in segments such as automotive fabrics, fabrics for hotel use, always at lower costs and with greater durability over time.

\section{REFERENCES}

1GOMES, Anne Velloso Sarmento; COSTA, Ney Róblis Versiani; MOHALLEM, Nelcy Della Santina. Os Tecidos e a Nanotecnologia. Revista Química Nova na Escola, v. 38, n. 4, p. 288-296, 2016. 
${ }^{2}$ CORADI, Michaela et al. Têxteis antimicrobianos produzidos pela modificação superficial de tecidos de algodão e imobilização de enzima pectinolítica. 2018.

${ }^{3}$ DE MAGALHÃES, Andreia Patrícia Sousa Alves. Atividade antimicrobiana em têxteis. 2015.

4PURWAR, Roli. Antimicrobial textiles. In: The Impact and Prospects of Green Chemistry for Textile Technology. Woodhead Publishing, 2019. p. 281-306.

${ }^{5}$ FEITOR, Michele Cequeira. Efeito antibacteriano de tecidos têxteis revestidos por prata através da técnica de deposição por plasma. 2010.

${ }^{6}$ WINDLER, Lena; HEIGHT, Murray; NOWACK, Bernd. Comparative evaluation of antimicrobials for textile applications. Environment international, v. 53, p. 62-73, 2013.

${ }^{7}$ RISTIĆ, Tijana et al. Antimicrobial efficiency of functionalized cellulose fibres as potential medical textiles. Science against microbial pathogens: communicating current research and technological advances, v. 6, p. 36-51, 2011.

'DADVAR, S.; OROUMEI, A. PRESENT AND FUTURE PROSPECTUSES OF ANTIBACTERIAL COATING OF TEXTILES. Journal of Characterization and Development of Novel Materials, v. 4, n. 2, p. 135, 2012.

${ }^{8} \mathrm{GAO}$, Yuan; CRANSTON, Robin. Recent advances in antimicrobial treatments of textiles. Textile research journal, v. 78, n. 1, p. 60-72, 2008.

${ }^{9}$ ESTEVES, Daniel Ferreira. Aperfeiçoamento das técnicas de avaliação da actividade antrimicrobiana em produtos Têxteis. 2009. Tese de Doutorado. Universidade da Beira Interior.

${ }^{10 I L I C ́}$, Vesna et al. Antifungal efficiency of corona pretreated polyester and polyamide fabrics loaded with Ag nanoparticles. Journal of materials science, v. 44, n. 15, p. 3983-3990, 2009.

${ }^{11} \mathrm{GAO}$, Yuan; CRANSTON, Robin. Recent advances in antimicrobial treatments of textiles. Textile research journal, v. 78, n. 1, p. 60-72, 2008. 